OAK RIDGE

NATIONAL LABORATORY MANAGED BY UT-BATTELLE

FOR THE DEPARTMENT OF ENERGY

\title{
ACTIVITY SUMMARY OF THE INCLUSION SURVEY CONTRACTOR FOR THE URANIUM MILL TAILINGS REMEDIAL ACTION PROJECT FROM 1983 TO 1998
}

M. J. Wilson-Nichols

C. A. Little

J. E. Wilson 


\title{
ACTIVITY SUMMARY OF THE INCLUSION SURVEY CONTRACTOR FOR THE URANIUM MILL TAILINGS REMEDIAL ACTION PROJECT FROM 1983 TO 1998
}

\author{
M. J. Wilson-Nichols \\ C. A. Little \\ J. E. Wilson \\ Environmental Technology Section \\ Life Sciences Division \\ Grand Junction, Colorado
}

Date Published: September 2000

\author{
Prepared by \\ OAK RIDGE NATIONAL LABORATORY \\ Oak Ridge, Tennessee 37831 \\ managed by \\ UT-BATTELLE, LLC \\ for the \\ U.S. DEPARTMENT OF ENERGY \\ under contract DE-AC05-00OR22725
}




\section{ACKNOWLEDGMENTS}

These authors wish to acknowledge the many technical and administrative personnel that supported this project throughout its duration including Marcy L. Espegren, Judith A. Rice, Caroline D. Retolaza, Timi Meyer, Penny Roundtree, Gretchen Pierce, Steve Hall, Kirk Roemer, Mark Mumby, Melissa Jensen and the many others that served the inclusion survey contractor throughout the years. 
. 


\section{CONTENTS}

\section{Page}

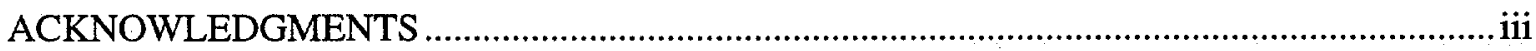

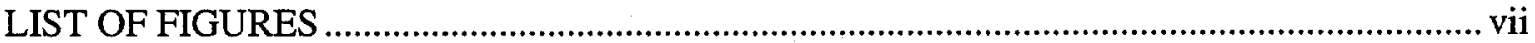

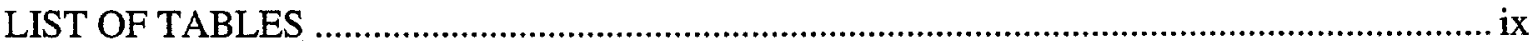

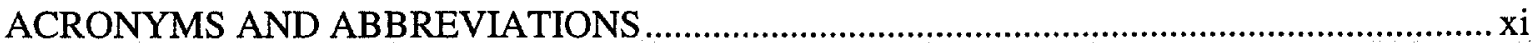

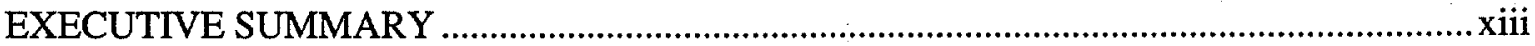

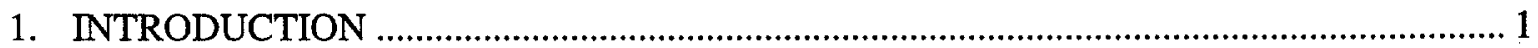

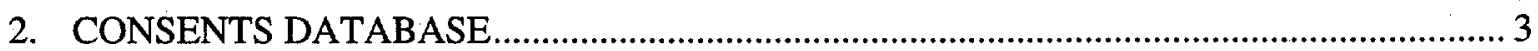

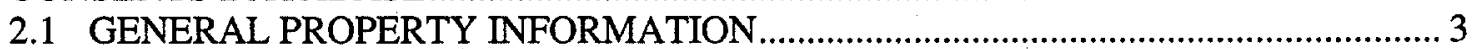

2.2 INCLUSION AND EXCLUSION RECOMMENDATIONS …................................... 4

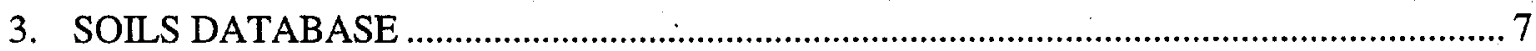

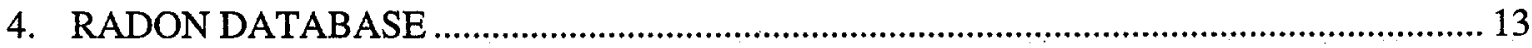

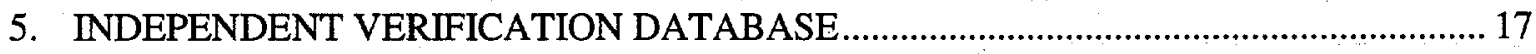

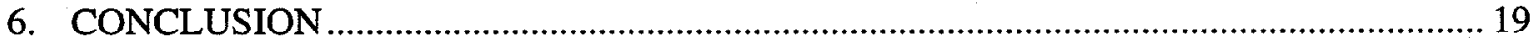

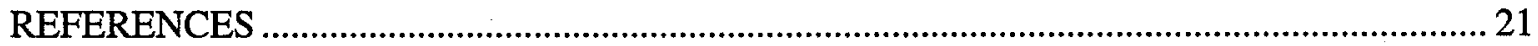

Appendix A. PUBLICATIONS, CONFERENCE PROCEEDINGS, AND TECHNICAL MEMORANDA. 


\section{LIST OF FIGURES}

Figure

$1 \quad$ Normal probability plot of ${ }^{226} \mathrm{Ra}$ in soil from the Grand Junction site ....................... 10

$2 \quad$ Normal probability plot of ${ }^{226} \mathrm{Ra}$ in soil from the Durango site ................................. 10

$3 \quad$ Normal probability plot of ${ }^{226} \mathrm{Ra}$ in soil from the Rifle site.................................... 11

$4 \quad$ Normal probability plot of ${ }^{226} \mathrm{Ra}(<100 \mathrm{pCi} / \mathrm{g})$ from the Grand Junction site ............. 11

$5 \quad$ Normal probability plot of ${ }^{226} \mathrm{Ra}$ in concrete from the Grand Junction site ............... 12 


\section{LIST OF TABLES}

Table

Page

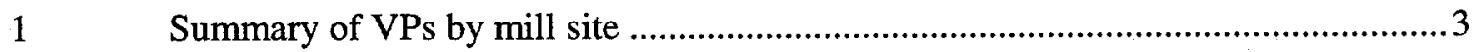

$2 \quad$ Classification of VPs evaluated for the UMTRA Project........................................4

3 Recommendation basis for evaluating VPs for the UMTRA Project........................5

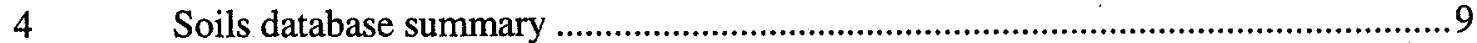

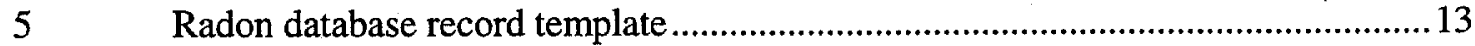

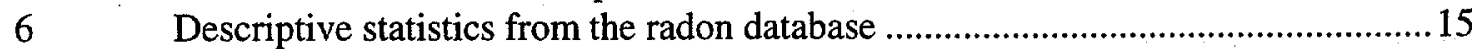




\section{ACRONYMS AND ABBREVIATIONS}

CFR

DOE

EDX

GJO

GJPO

GJRAP

GS

ISC

IVC

MDA

$\mu \mathrm{R} / \mathrm{h}$

NORM

ORNL

$\mathrm{pCi} / \mathrm{g}$

PNNL

RAC

RDC

UMTRA

UMTRCA

VP

WL
Code of Federal Regulations

U.S. Department of Energy

Environmental Data Explorer

Grand Junction Office

Grand Junction Project Office

Grand Junction Remedial Action Program

gamma spectrometer

Inclusion Survey Contractor

Independent Verification Contractor

minimal detectable activity

micro-roentgen per hour

natural-occurring radioactive material

Oak Ridge National Laboratory

picocuries per gram

Pacific Northwest National Laboratory

Remedial Action Contractor

Radon Daughter Concentration

Uranium Mill Tailings Remedial Action

Uranium Mill Tailings Radiation Control Act of 1978

vicinity property

working level 


\section{EXECUTIVE SUMMARY}

The Oak Ridge National Laboratory, Grand Junction, Colorado, office was the Inclusion Survey Contractor and the Independent Verification Contractor (IVC) for the Uranium Mill Tailings Remedial Action (UMTRA) Project from 1983 to 1998. This report summarizes the activities performed during this time and discusses data collected and stored in four databases.

The primary project management database contains 13,937 records that hold key information and logistics about each vicinity property. The second database contains technical information such as measurements for analysis of ${ }^{226} \mathrm{Ra}$ in soil and concrete samples. A third database contains radon daughter concentrations. Finally, properties and pertinent information regarding the IVC effort are stored in a fourth database. These databases are available on CD and are stored in the archives at the Department of Energy's Grand Junction Office.

The analytical database is particularly valuable because it contains nearly $20,000{ }^{226} \mathrm{Ra}$ results. Descriptive statistics of these data provide a variety of insights into the nature of milltailings contamination and also background levels of ${ }^{226} \mathrm{Ra}$ at the UMTRA Project sites. 


\title{
ACTIVITY SUMMARY OF THE INCLUSION SURVEY CONTRACTOR FOR THE URANIUM MILL TAILINGS REMEDIAL ACTION PROJECT FROM 1983 TO 1998
}

\author{
M. J. Wilson-Nichols \\ C. A. Little \\ J. E. Wilson
}

\section{INTRODUCTION}

Uranium ore was processed in mills throughout the United States from the early 1940s through 1970 by private companies under contract with the Manhattan Engineering District and the U.S. Atomic Energy Commission. As the demand for processed uranium decreased, the mills were deactivated, leaving large quantities of mill tailings behind. These tailings were composed of a sandlike material and often accessible to the public for use in various construction projects. When research suggested that there were potential health effects from low-level radiation (primarily from inhalation of radon progeny), local and federal government agencies became concerned. Congress passed public laws that provided funds for cleanup as early as 1972 (DOE 1988). In November 1978, Public Law 95-604, the Uranium Mill Tailings Radiation Control Act of 1978 (UMTRCA) was passed. UMTRCA required that the federal government perform remedial actions on inactive uranium mill-tailings sites that had been used by the federal government as well as properties where tailings from the sites had been used for construction, called vicinity properties (VPs).

Oak Ridge National Laboratory (ORNL) was assigned the responsibility of the Inclusion Survey Contractor (ISC) for the Uranium Mill Tailings Remedial Action (UMTRA) Project by the U.S. Department of Energy (DOE) in 1983. The role of the ISC was to investigate VPs to determine whether they qualified for remedial action according to the standards set forth in Title 40 Code of Federal Regulations (CFR) No. 192 (EPA 1983). Based on the ISC investigations, recommendations were provided to DOE, which made the decision to include or exclude a VP from the UMTRA Project. Including a property meant that it was slated for cleanup. Properties investigated were provided from designation lists resulting from previous surveys or owner requests (Espegren et al. 1987). In addition, DOE advertised the UMTRA Project, soliciting property owners who suspected the presence of uranium mill tailings to request a survey. ORNL constructed four databases to serve the UMTRA Project: (1) owner information and pertinent dates, (2) ${ }^{226} \mathrm{Ra}$ analytical results, (3) ${ }^{222} \mathrm{Rn}$ results, and (4) independent verification data. These databases are attached as Appendixes $A$ through $D$, respectively, and summarized below as part of the final project closeout. Appendix A provides a list of publications, conference proceedings, and technical memorandums produced by the ORNL Grand Junction Office (GJO) as part of the UMTRA Project ISC.

In addition to the ISC responsibility, ORNL played a limited role as the Independent Verification Contractor (IVC) for VPs in Grand Junction, Colorado. The role of the IVC was to show compliance to UMTRA guidelines and criteria by the Remedial Action Contractor (RAC) after and during remedial action. Approximately $10 \%$ of the remediated properties were surveyed by the IVC. 
Four databases were constructed to serve various needs of the inclusion and independent verification survey process. They were originally programmed in KnowledgeMan, an early database language. The databases were converted to FoxPro to provide easily accessible information for the UMTRA Project Archive. The databases summarize ORNL ISC and IVC roles and are discussed in the following chapters. 


\section{CONSENTS DATABASE}

The consents database contains basic information for each VP. The information includes specific project number, property classification, property address, and legal parcel numbers. The database was also designed to track dates of the inclusion survey process along with the initials of technical and administrative personnel who conducted the work. Entered initials and dates include land survey, drafting, assignment of the property to a field team leader, and recommendation for inclusion/exclusion. The database holds various comments regarding the specifics of each property and other pertinent dates.

\subsection{GENERAL PROPERTY INFORMATION}

There are 13,937 records in the consents database that represent the entire population of VPs. These properties represent a site where the ISC provided an inclusion/exclusion recommendation. The 23 UMTRA Project sites are shown in Table 1.

Table 1. Summary of VPs by mill site

\begin{tabular}{|c|c|c|c|c|c|c|}
\hline Code & Location & $\begin{array}{l}\text { Number } \\
\text { of VPs }\end{array}$ & Inclusions & Exclusions & Closed & Street \\
\hline $\mathrm{AM}$ & Ambrosia Lake, NM & 5 & 5 & & & \\
\hline $\mathrm{BF}$ & Belfield, ND & 20 & 7 & 12 & 1 & \\
\hline BO & Bowman, ND & 3 & 1 & 2 & & \\
\hline $\mathrm{CA}$ & Canonsburg, PA & 380 & 162 & 189 & 29 & \\
\hline DU & Durango, CO & 551 & 124 & 397 & 22 & 8 \\
\hline $\mathrm{ED}$ & Edgemont, SD & 250 & 136 & 113 & 1 & \\
\hline $\mathrm{FC}$ & Falls City, TX & 27 & 9 & 18 & & \\
\hline GJ & Grand Junction, CO & 11,256 & 4,377 & 6,620 & 259 & \\
\hline GR & Green River, UT & 46 & 17 & 24 & 5 & \\
\hline GU & Gunnison, $\mathrm{CO}$ & 50 & 12 & 38 & & \\
\hline LK & Lakeview, OR & 13 & 8 & 5 & & \\
\hline LO & Lowman, ID & 63 & 38 & 22 & 3 & \\
\hline MB & Maybell, CO & 22 & 12 & 8 & 2 & \\
\hline MH & Mexican Hat, UT & 34 & 11 & 23 & & \\
\hline MV & Monument Valley, AZ & 23 & 4 & 18 & 1 & \\
\hline NT & Naturita, $\mathrm{CO}$ & 224 & 53 & 166 & 5 & \\
\hline RF & Rifle, CO & 592 & 113 & 459 & 20 & \\
\hline RT & Riverton, WY & 105 & 41 & 61 & 3 & \\
\hline SH & Shiprock, NM & 21 & 15 & 6 & & \\
\hline SK & Douglas, WY & 2 & 2 & & & \\
\hline SL & Salt Lake City, UT & 187 & 119 & 63 & 5 & \\
\hline SR & Slick Rock, CO & 53 & 16 & 34 & 3 & \\
\hline \multirow[t]{2}{*}{$\mathrm{TC}$} & Tuba City, AZ & 10 & 1 & 8 & 1 & - \\
\hline & Totals & 13,937 & 5,283 & 8,286 & 360 & 8 \\
\hline
\end{tabular}


By far, the largest number of VPs were located in Grand Junction $(11,256)$, followed by Rifle (592), and Durango (591). Hence the convenient location of the ORNL ISC office at the Grand Junction Project Office (GJPO) of the DOE. Surveys were conducted from 1978 in Cannonsburg, Pennsylvania, to 1998 in Grand Junction, Colorado. A total of 5,283 properties (38\%) were recommended for inclusion, and $59 \%$ were recommended to be excluded from the project by the ISC. The remaining $3 \%$ were portions of public streets, and also some duplicates and other circumstances where location numbers were "closed out". (Table 1).

Properties investigated by the ISC consisted of various land uses as shown in Table 2. Most VPs consisted of single-family residences $(63 \%)$. Of the single-family residences, approximately $33 \%$ were recommended for inclusion in the UMTRA Project; $67 \%$ of these residences were excluded from the project. Properties classified as schools had a large percentage (78\%) of inclusions (105 of 134). Similar inclusion rates occurred with other public properties because the mill tailings were accessible and of no cost to builders at the time of construction. This cost savings was particularly economical to large construction projects such as parks, schools, and commercial structures (Table 2).

Table 2. Classification of VPs evaluated for the UMTRA Project

\begin{tabular}{|c|c|c|c|c|c|c|}
\hline Class & Description & $\begin{array}{c}\text { Number of } \\
\text { VPs }\end{array}$ & Inclusion & Exclusion & Closed & Street \\
\hline AP & Apartment ( $>4$ families) & 172 & 55 & 108 & 9 & \\
\hline $\mathrm{CC}$ & Complex commercial $(>\$ 350,000)$ & 266 & 157 & 107 & 2 & \\
\hline $\mathrm{CH}$ & Church & 59 & 26 & 32 & 1 & \\
\hline CS & Commercial structure & 1,632 & 766 & 848 & 18 & \\
\hline DT & Dovetail (UMTRA and GJRAP) & 159 & 122 & 37 & & \\
\hline $\mathrm{HO}$ & Hotel or hospital & 38 & 30 & 8 & & \\
\hline $\mathrm{MO}$ & Motel (single-story structure) & 26 & 10 & 15 & 1 & \\
\hline MR & Major residence & 352 & 326 & 26 & & \\
\hline OT & Other & 544 & 334 & 195 & 7 & 8 \\
\hline $\mathrm{RM}$ & Multiple-family residence $(1-4)$ & 495 & 134 & 351 & 10 & \\
\hline RS & Single-family residence & 8,738 & 2,711 & 5,818 & 209 & \\
\hline $\mathrm{SC}$ & School & 134 & 105 & 28 & 1 & \\
\hline SI & Site (treated as part of mill site) & 28 & 5 & & 23 & \\
\hline UK & Unknown & 22 & 15 & 2 & 5 & \\
\hline \multirow[t]{3}{*}{ VL } & Vacant lot & 1,014 & 354 & 653 & 7 & \\
\hline & (Class not documented) & 258 & 133 & 58 & 67 & - \\
\hline & Totals & 13,937 & 5,283 & 8,286 & 360 & 8 \\
\hline
\end{tabular}

\subsection{INCLUSION AND EXCLUSION RECOMMENDATIONS}

Table 3 summarizes the statistics describing the recommendation basis of the inclusion and exclusion of VPs. The first four criteria in Table 3 (indoor gamma, radon, outdoor gamma, and soils) are described in 40 CFR 192 . Spillover, the fifth criteria, was used when a large deposit of mill tailings was found to overlap property boundaries. In this case, the adjacent property was usually not surveyed by the ISC, but automatically included in the UMTRA Project. As Table 3 
Table 3. Recommendation basis for evaluating VPs for the UMTRA Project

\begin{tabular}{|c|c|c|c|c|c|c|c|c|c|}
\hline \multicolumn{5}{|c|}{ Evaluation criteria } & \multirow[b]{2}{*}{$\begin{array}{c}\text { Number of } \\
\text { VPs }\end{array}$} & \multirow[b]{2}{*}{ Inclusions } & \multirow[b]{2}{*}{ Exclusions } & \multirow[b]{2}{*}{ Closed } & \multirow[b]{2}{*}{ Street } \\
\hline $\begin{array}{l}\text { Indoor } \\
\text { gamma }\end{array}$ & Radon & $\begin{array}{c}\text { Outdoor } \\
\text { gamma }\end{array}$ & $\begin{array}{c}\text { Radium } \\
\text { in soil }\end{array}$ & Spillover & & & & & \\
\hline $\mathbf{X}$ & $\mathbf{X}$ & $\mathbf{X}$ & $\mathbf{X}$ & & 2 & & 2 & & \\
\hline $\mathbf{X}$ & $\mathbf{X}$ & $\mathrm{X}$ & & & 7 & 2 & 5 & & \\
\hline $\mathbf{X}$ & $\mathbf{X}$ & & $\mathbf{X}$ & & 6 & & 6 & & \\
\hline $\mathbf{X}$ & $\mathbf{X}$ & & & & 6 & 1 & 5 & & \\
\hline $\mathbf{X}$ & & $\mathbf{X}$ & $\mathbf{X}$ & . & 248 & 50 & 198 & & \\
\hline $\mathbf{X}$ & & $\mathbf{X}$ & & & 5,159 & 65 & 5,094 & & \\
\hline $\mathbf{X}$ & & & $\mathbf{X}$ & & 1,102 & 61 & 1,041 & & \\
\hline $\mathbf{X}$ & & & & $\mathbf{X}$ & 1 & 1 & & & \\
\hline \multirow[t]{14}{*}{$\mathbf{X}$} & & & & & 468 & 378 & 90 & & \\
\hline & $\mathbf{X}$ & $\mathbf{X}$ & $\mathbf{X}$ & & 8 & & 8 & & \\
\hline & $\mathbf{X}$ & $\mathbf{X}$ & & & 152 & & 152 & & \\
\hline & $\mathbf{X}$ & & $\mathbf{X}$ & & 123 & 6 & 117 & & \\
\hline & $\mathbf{X}$ & & & & 88 & 87 & 1 & & \\
\hline & & $\mathbf{X}$ & $\mathbf{X}$ & $\mathbf{X}$ & 3 & 3 & & & \\
\hline & & $\mathbf{X}$ & $\mathbf{X}$ & & 496 & 255 & 241 & & \\
\hline & & $\mathbf{X}$ & & $\mathbf{X}$ & 10 & 9 & 1 & & \\
\hline & & $\mathbf{X}$ & & & 1,406 & 522 & 884 & & \\
\hline & & & $\mathbf{X}$ & $\mathbf{X}$ & 29 & 29 & & & \\
\hline & & & $\mathbf{X}$ & & 2,679 & 2,531 & 148 & & \\
\hline & & & & $\mathbf{X}$ & 210 & 204 & 6 & & \\
\hline & & & & & $1,734^{a}$ & 1,079 & 287 & 360 & 8 \\
\hline & & & & & 13,937 & 5,283 & 8,286 & 360 & 8 \\
\hline
\end{tabular}

${ }^{a}$ Evaluated by other contractors, or as part of a previous remedial action program (historical inclusion). 
shows, the criteria are not mutually exclusive. In many cases, uranium mill tailings were used for both building materials and fill material for landscape or beneath walkways. Therefore, both indoor and outdoor criteria might be exceeded. The majority of the VPs were evaluated on the basis of indoor/outdoor gamma and radium-in-soil (5,159 and 2,679, respectively). This is followed by those properties that were evaluated only on the basis of radium-in-soil. Interestingly, the recommendations for inclusion based on radon [radon daughter concentrations (RDCs)] were few compared to the other criteria. Although radon was the driving force and primary health concern, its measurement was difficult due to the long period of time the device was to remain in place and the question of reliability of measurement. The majority of buildings measured for RDC ( $296 / 392$ or $75 \%$ ) were excluded from further action. There were 1,734 properties that were evaluated by other contractors or as part of a previous remedial action program. 


\section{SOILS DATABASE}

The soils database includes pertinent information regarding samples collected during the radiological survey and submitted to the ORNL/GJO soils laboratory for analysis of ${ }^{226} \mathrm{Ra}$. Potassium $(\mathrm{K})$ and ${ }^{230} \mathrm{Th}$ values were also calculated for samples. Not all properties surveyed by the ISC had a soil sample because soils samples were only required when gamma exposure rates were elevated and mill tailings were suspected to be present. This database also provides the location of the sample in each respective waste barrel. Since the end of the project, these barrels have been transported to the DOE UMTRAP repository known as Cheney Reservoir for disposal. The ORNL Procedures Manual describes the collection and analysis of soils in detail (ORNL 1994). A unique alpha-numeric identification was assigned to each soil sample. Although this technique changed over time, the sample identification scheme was as follows for most of the project duration:

Sample 1, surface only:

Sample 2, same property:

or

\section{Sample 1}

1 - to $15-\mathrm{cm}$ deep (surface):

15- to $30-\mathrm{cm}$ deep (subsurface):

30- to 45-cm deep (subsurface):

Concrete sample:

From beneath slab:
$\mathrm{AB} 1234 \mathrm{~S} 1$

$\mathrm{AB} 1234 \mathrm{~S} 2$

where
$\mathrm{AB} 01234 \mathrm{~S} 1 \mathrm{~A}$
AB01234S1B
$\mathrm{AB} 01234 \mathrm{S1C}$, etc.
$\mathrm{AB} 01234 \mathrm{~S} 1 \mathrm{Z}$
AB01234S1U
AB site location code (i.e., GJ = Grand Junction, etc.)
01234 location number
S1 (or S2) sample number
A sample depth, 0 to $15 \mathrm{~cm}$
B sample depth, 15 to $30 \mathrm{~cm}$
C sample depth, etc.

Other sample identification numbers in the soils database included:

$\begin{array}{ll}\text { V } & \text { verification composite } \\ \text { B } & \text { biased sample } \\ \text { X } & \text { verification split sample } \\ \text { T } & \text { special study of Tordilla Creek, Fall City } \\ \text { R } & \text { resurvey or resample } \\ \text { F } & \text { fly ash }\end{array}$

Several insignificant sample identification labels for special studies and projects were conducted during inclusion surveys. These are comprised of fly ash samples and samples from Tordilla Creek, as shown above, which are excluded from the statistics discussed in the following paragraphs. 
The ORNL/GJO soils laboratory analyzed 19,573 inclusion survey samples from April 1985 to September 1997. Samples in this database are summarized in Table 4 and include those collected as part of the ORNL IVC effort.

The majority of the samples $(9,243)$ were soil samples collected in Grand Junction (Table 4). The remote site samples (such as Durango and Rifle) were generally soil samples (vs concrete or other). Biased samples usually represented single questionable locations, and often where those were high in ${ }^{226} \mathrm{Ra}$ concentration. The maximum ${ }^{226} \mathrm{Ra}$ concentration in the database was $14,626(\mathrm{pCi} / \mathrm{g}$ ), and it is from a point source sample (radium dial or uranium ore) vs mill tailings. Usually samples were not collected from point sources; however, in circumstances where the point source was not readily evident (i.e., visible) a sample was collected. Indeed, samples with ${ }^{226} \mathrm{Ra}$ concentrations above approximately $1000 \mathrm{pCi} / \mathrm{g}$ are likely to have contained point source material. A total of 981 concrete samples reflect the use of mill tailings as a concrete matrix in construction projects, with ${ }^{226} \mathrm{Ra}$ in concrete samples ranging as high as $850 \mathrm{pCi} / \mathrm{g}$. However, constituents of concrete may also contain natural-occurring radioactive material (NORM) from various rock types used as aggregate.

Figures 1 through 3 are normal probability plots of the ISC data from the Grand Junction, Durango, and Rifle sites, respectively. Normal probability plots and threshold calculations were performed using Environmental Data Explorer (EDX). EDX was developed by Pacific Northwest National Laboratory (PNNL) under contract to ORNL/GJO as part of an on-going program to enhance the use of statistical techniques in the evaluation of environmental data. EDX employs the program "R" (version 0.6.1), free software, which is similar to "S-Plus" with a "copy-left" agreement (open-source code).

The skewness (a measure of the symmetry of a distribution) was calculated by the EDX code. By definition, the threshold is regarded as the practical upper limit of the background population (Korte 1999). The minimal detectable activity (MDA) is considered the low end of the population range and the threshold the high end of the range. Calculated thresholds were $14.7 \mathrm{pCi} / \mathrm{g}$ for Grand Junction, $3.89 \mathrm{pCi} / \mathrm{g}$ for Durango, and $5.77 \mathrm{pCi} / \mathrm{g}$ for Rifle. Interestingly, this threshold nears the 15-pCi/g limit for subsurface soils in Grand Junction and exceeds the value of $5 \mathrm{pCi} / \mathrm{g}$ for surface soil with respect to area. To better view the distribution for Grand Junction, values above $100 \mathrm{pCi} / \mathrm{g}$ were eliminated and the normal probability plot recreated (Fig. 4). The results suggest not only two populations represented in the sample set, but also a third population above approximately $90 \mathrm{pCi} / \mathrm{g}$ (Fig. 4). The threshold calculated in Fig. 4 is similar to that of Fig. 1, where the entire data set was plotted (14.28 vs $14.7 \mathrm{pCi} / \mathrm{g})$.

Figure 5 shows a probability plot of ${ }^{226} \mathrm{Ra}$ in concrete. This may not be as significant as the soil plots, but there is a distinct hinge at $18.64 \mathrm{pCi} / \mathrm{g}$. Possibly, the two populations are due to NORM used as aggregate vs the higher mill-tailings sand as previously mentioned. 
Table 4. Soils database summary

\begin{tabular}{|c|c|c|c|c|c|c|c|c|c|c|c|}
\hline \multirow[b]{2}{*}{ Location } & \multirow{2}{*}{$\begin{array}{l}\text { Number of } \\
\text { samples }\end{array}$} & \multirow[b]{2}{*}{ Biased } & \multirow[b]{2}{*}{ Concrete } & \multirow[b]{2}{*}{ Resample } & \multirow[b]{2}{*}{ Soil } & \multirow[b]{2}{*}{ Verf comp } & \multirow[b]{2}{*}{ Verf split } & \multicolumn{4}{|c|}{${ }^{226} \mathrm{Ra}(\mathrm{pCi} / \mathrm{g})$} \\
\hline & & & & & & & & Minimum & Maximum & $\begin{array}{c}\text { Mean } \\
\text { average }\end{array}$ & Median \\
\hline BF & 31 & & & & 31 & & & 1.47 & 327.00 & 69.52 & 25.60 \\
\hline $\mathrm{BO}$ & 4 & & & & 4 & & & 1.33 & 6.02 & 3.68 & 3.68 \\
\hline $\mathrm{CA}$ & 285 & 79 & $\therefore$ & 5 & 201 & & & 0.55 & 487.00 & 12.44 & 3.48 \\
\hline DU & 723 & 214 & 8 & 10 & 491 & & & 0.62 & 631.67 & 20.72 & 3.89 \\
\hline ED & 265 & & & & 261 & & 4 & 0.63 & 534.00 & 18.24 & 4.49 \\
\hline $\mathrm{FC}$ & 207 & & & & 207 & & & 0.50 & 147.00 & 17.76 & 7.64 \\
\hline GJ & 16,201 & 2,473 & 956 & 774 & 9,243 & 1022 & 1733 & -0.56 & $8,970.00$ & 36.50 & 10.10 \\
\hline GR & 87 & & & & 87 & & & 0.81 & $3,380.00$ & 68.07 & 8.42 \\
\hline GU & 56 & & & & 56 & & & 0.42 & 66.30 & 15.33 & 13.20 \\
\hline LK & 7 & & & & 7 & & & 1.50 & 39.70 & 10.46 & 1.50 \\
\hline LO & 110 & & & & 110 & & & 0.69 & $1,045.00$ & 94.14 & 32.10 \\
\hline $\mathrm{MB}$ & 16 & & & & 16 & & & 0.69 & 39.50 & 16.07 & 9.47 \\
\hline $\mathrm{MH}$ & 2 & 2 & & & & & & 1.50 & 1.50 & 1.50 & 1.50 \\
\hline MV & 1 & 1 & 8 & & & & & 52.94 & 52.94 & 52.94 & 52.94 \\
\hline $\mathrm{NT}$ & 240 & 6 & 5 & 10 & 219 & & & 1.48 & $7,800.00$ & 158.05 & $16 . \overline{75}$ \\
\hline $\mathrm{RF}$ & 930 & 16 & 12 & & 902 & & & 0.00 & $3,271.00$ & 17.92 & 4.82 \\
\hline $\mathrm{RT}$ & 87 & 43 & & & 44 & & & 0.88 & $1,057.00$ & 91.89 & 7.91 \\
\hline $\mathrm{SH}$ & 29 & 28 & & & 1 & & & 1.17 & 24.80 & 5.12 & 2.57 \\
\hline SK & 6 & & & & 6 & & & 2.15 & 256.00 & 79.26 & 10.89 \\
\hline SL & 249 & 107 & & & 142 & & & 0.00 & $14,626.00$ & 118.72 & 4.72 \\
\hline SR & 32 & & & & 32 & & & 0.84 & 466.00 & 68.81 & 48.00 \\
\hline $\mathrm{TC}$ & 5 & 5 & & & & & & 1.55 & 59.92 & 15.05 & 5.41 \\
\hline Totals & 19,573 & 2,974 & 981 & 799 & 12,060 & 1022 & 1737 & & & & \\
\hline
\end{tabular}




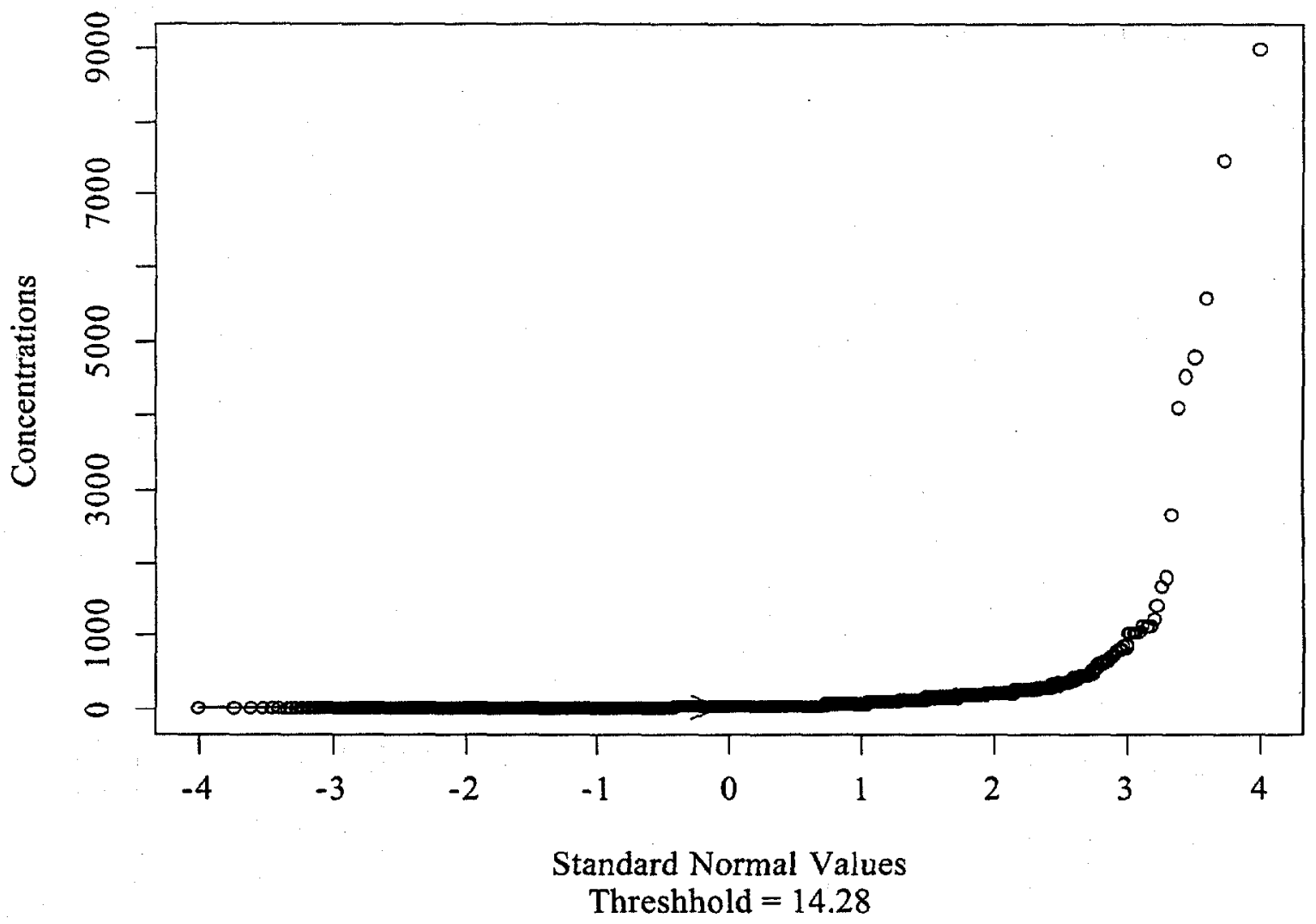

Fig. 1. Normal probability plot of ${ }^{226} \mathrm{Ra}$ in soil, where $\mathrm{n}=9.243$, from the Grand Junction site.

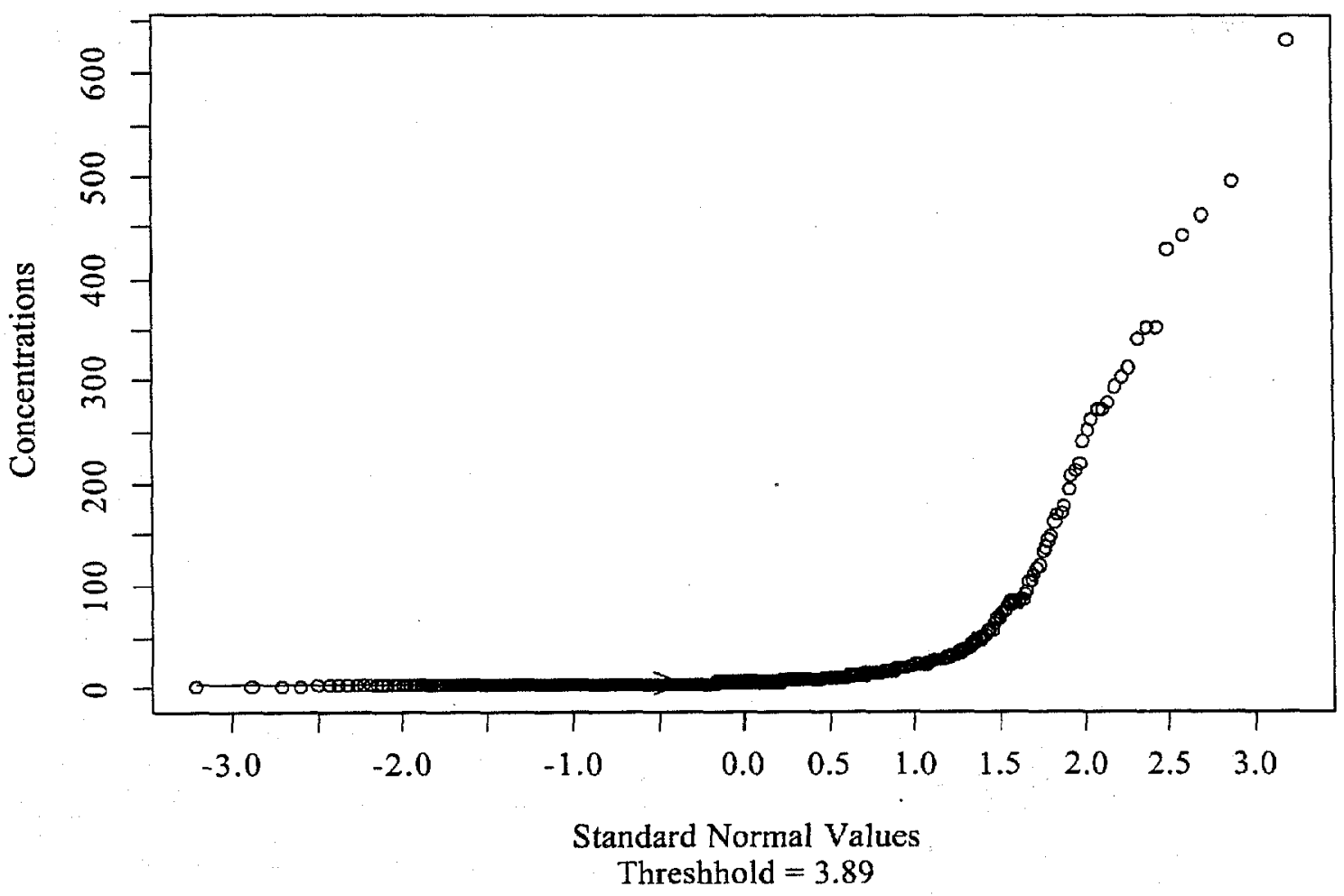

Fig. 2. Normal probability plot of ${ }^{226} \mathrm{Ra}$ in soil from the Durango site. 


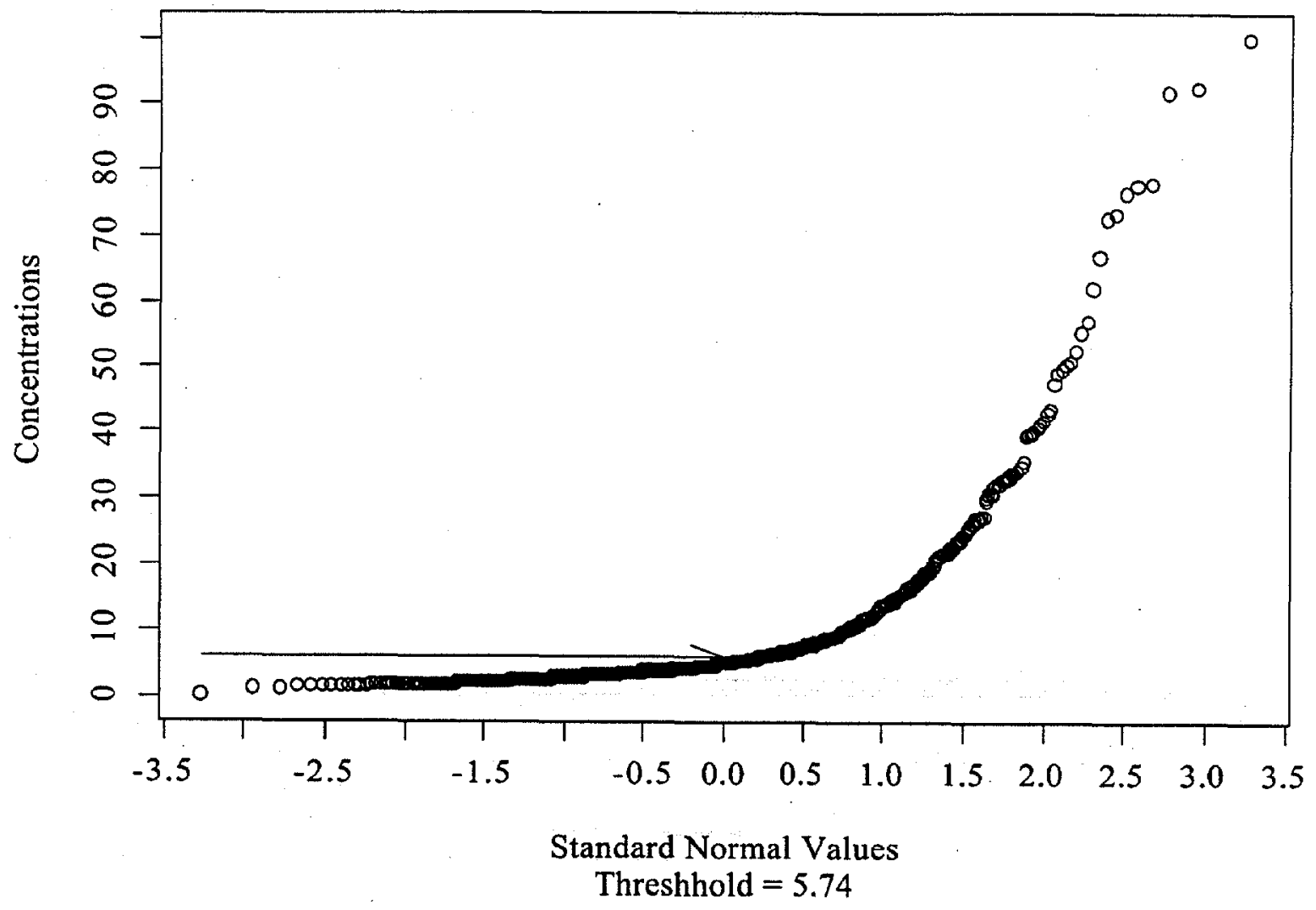

Fig. 3. Normal probability plot of ${ }^{226} \mathrm{Ra}$ in soil from the Rifle site.

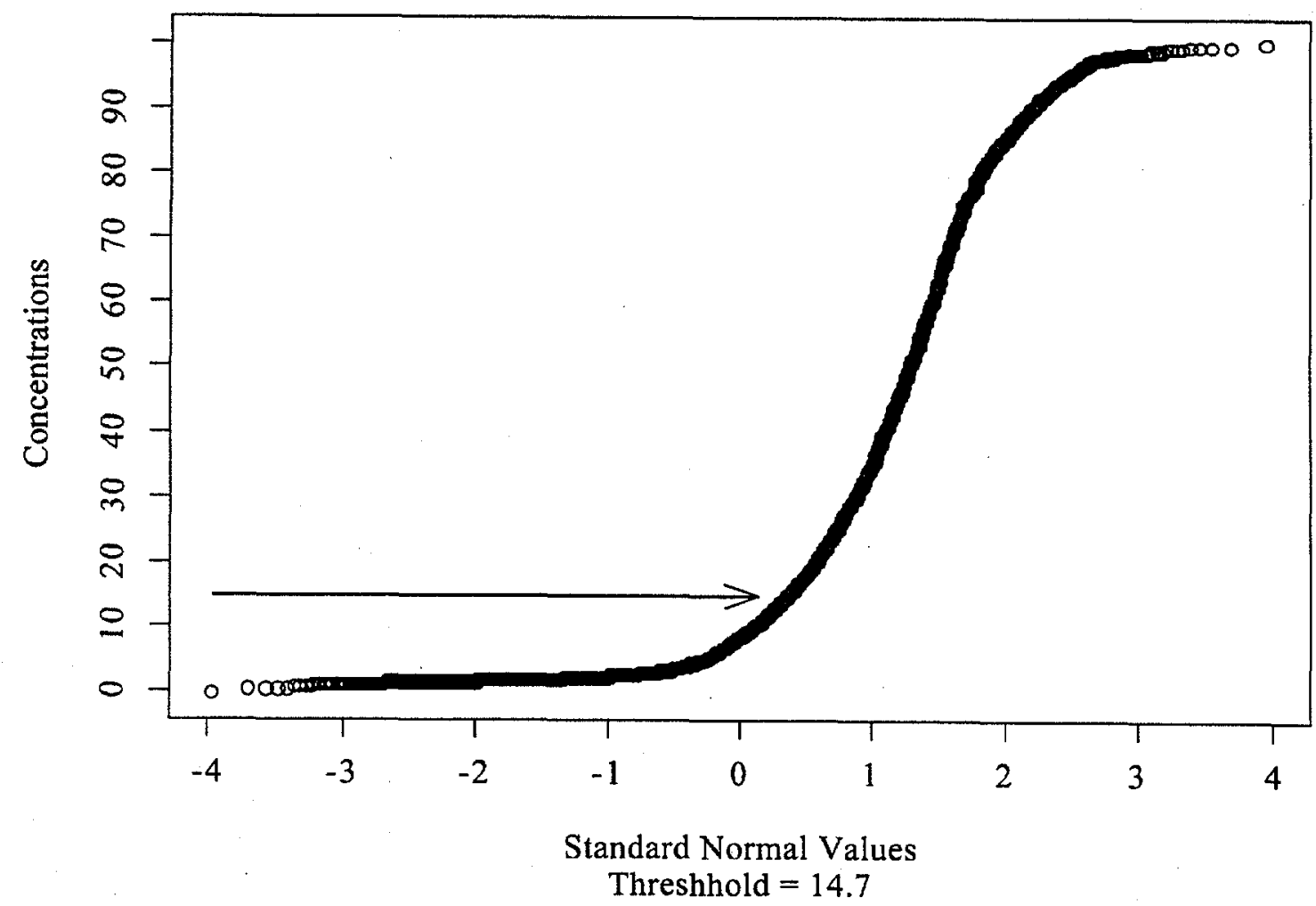

Fig. 4. Normal probability plot of ${ }^{226} \mathrm{Ra}(<100 \mathrm{pCi} / \mathrm{g})$ from the Grand Junction site. 


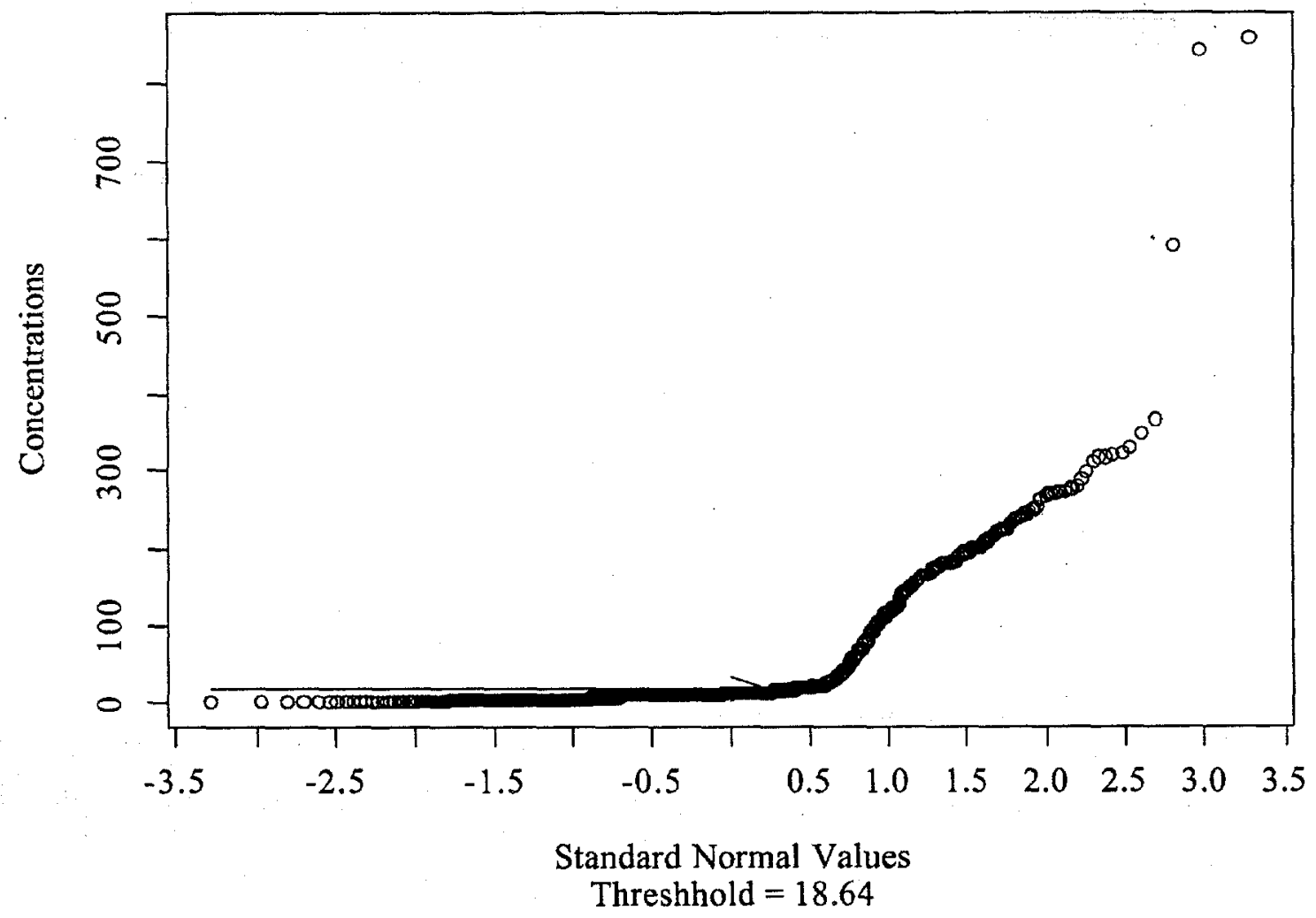

Fig. 5. Normal probability plot of ${ }^{226} \mathrm{Ra}$ in concrete from the Grand Junction site. 


\section{RADON DATABASE}

The radon database provides technical information regarding properties that were measured for RDC. However, this measurement was not taken on all properties, but only those properties with gamma radiation that fell into a "gray" area. This was defined as an area indoors that was between the guideline of $20 \mu \mathrm{R} / \mathrm{h}$ above background and the background gamma radiation average plus approximately $30 \%$. The ORNL procedures manual describes this case in detail (ORNL 1994).

A template of the radon database record is provided in Table 5 as a key to the codes provided in Sect. 3, and the descriptive statistics in Table 6. The radon database provides a variety of technical data that were electronically recorded from the ISC surveys. This database allows for some linear comparison of technical data such as gamma exposure rates related to RDC. Table 5 is an index to the fields contained in the radon database. The first properties measured for RDC were used as the basis of a study to determine the best brand of measurement devices to use in the project. It was agreed that the passive alpha-track measurement was the most accurate way to determine the average annual working level (WL) at a property. Two brands of alpha-track devices, termed "cups," were used in the study (Landauer ${ }^{\mathrm{TM}}$ and Terradex ${ }^{\mathrm{TM}}$ ). Three cups of each brand were placed in properties, and mean averages of the results were used in the ISC reports and recommendations. Eventually, the Landauer cup was selected as the sole measurement device based on the comparison study. This was because the triplicate measurements showed less variance than the corresponding Terradex brand devices. The mean average WL of the two measurement devices are relatively close $(0.017$ and 0.019$)$, as shown in Table 6. Note that the RDC measurements were converted from radon gas concentrations $(\mathrm{pCi} / \mathrm{L})$ assuming $50 \%$ equilibrium.

A total of 325 RDC measurements were collected between April 1986 and February 1997. Gamma exposure rates ranged from 1.9 to $63 \mu \mathrm{R} / \mathrm{h}$ with a mean average of $23 \mu \mathrm{R} / \mathrm{h}$. The combined RDC measurements of both brands of cups ranged from 0.0006 to $0.19 \mathrm{WL}$ and averaged 0.015 WL. Soil and concrete samples were associated with the location of RDC measurement on 59 and 63 locations, respectively. Soil samples ranged from 0.5 to $39.2 \mathrm{pCi} / \mathrm{g}$ and concrete from 0.5 to $199.5 \mathrm{pCi} / \mathrm{g}$, respectively (Table 6). Gamma spectrometer measurements were also collected at each location. These measurements were collected as part of a study to determine whether radium/thorium ratios of various locations could be used as an indicator of the type of contamination. No specific conclusions could be drawn with the data because the ratios seemed to vary widely and there are no linear relationships with any other measurements such as RDC or radium-in-soil concentrations.

Table 5. Radon database record template

\begin{tabular}{ll}
\hline \multicolumn{1}{c}{ Field Name } & \multicolumn{1}{c}{ Explanation } \\
\hline LOCNO & Location number (same as in the consents database) \\
ADDR & Address \\
OWNER & Owner \\
PLACED & The date when alpha-track cups were placed \\
PICKUP & The range of dates when cups were to be retrieved \\
DATE & The actual date the cups were retrieved \\
DAYS & The actual number of days that the cups were in place \\
GRANGE & The gamma range in which cups were placed in $\mu R / h$ \\
GAVG & The average gamma range in which cups were placed in $\mu R / h$
\end{tabular}


Table 5. (continued)

\begin{tabular}{|c|c|}
\hline Field Name & Explanation \\
\hline SQMETER & The size of the area represented by the measurement \\
\hline LCUP1 $^{a}$ & ID number of Landauer cup 1 \\
\hline LCUP2 & ID number of Landauer cup 2 \\
\hline LCUP3 & ID number of Landauer cup 3 \\
\hline LRN1 & Radon $(\mathrm{pCi} / \mathrm{L})$ value of Landauer cup 1 \\
\hline LRN2 & Radon (pCi/L) value of Landauer cup 2 \\
\hline LRN3 & Radon (pCi/L) value of Landauer cup 3 \\
\hline LWL1 & Working level value from Landauer cup 1 \\
\hline LWL2 & Working level value from Landauer cup 2 \\
\hline LWL3 & Working level value from Landauer cup 3 \\
\hline TCUP4 $^{b}$ & ID number of the Track-etch cup 4 \\
\hline TCUP5 & ID number of the Track-etch cup 5 \\
\hline TCUP6 & ID number of the Track-etch cup 5 \\
\hline TRN4 & Radon $(\mathrm{pCi} / \mathrm{L})$ value of Track etch cup 4 \\
\hline TRN5 & Radon (pCi/L) value of Track etch cup 5 \\
\hline TRN6 & Radon (pCi/L) value of Track etch cup 6 \\
\hline TWL4 & Working level value of Track etch cup 4 \\
\hline TWL5 & Working level value of Track etch cup 5 \\
\hline TWL6 & Working level value of Track etch cup 6 \\
\hline AAL & Mean working level of Landauer brand devices \\
\hline AAT & Mean working level of Track-etch brand devices \\
\hline WLAVG $^{c}$ & Mean working level of AAL and AAT \\
\hline FILMLO & Description of the location of the devices \\
\hline $\mathrm{GSTC}^{d}$ & Total counts-gamma spectrometer portable meter (GR-410) \\
\hline GSK & Potassium-gamma spectrometer portable meter \\
\hline GSRA & Radium-gamma spectrometer portable meter \\
\hline GSTH & Thorium-gamma spectrometer portable meter \\
\hline GSRATH & Radium/Thorium ratio from gamma spec portable meter \\
\hline CONC1 & Radium-in-concrete sample (pCi/g) if applicable \\
\hline CONC2 & Radium-in-concrete sample ( $\mathrm{pCi} / \mathrm{g}$ ) if applicable \\
\hline SOIL1 & Radium-in-soil sample (pCi/g) if applicable \\
\hline SOIL 2 & Radium-in-soil sample (pCi/g) if applicable \\
\hline AVGC & Average of the two concrete samples above if applicable \\
\hline AVGS & Average of the two soil samples above if applicable \\
\hline NEAWAC & Net estimated area weighted average of concrete sample average \\
\hline REM1 & Remarks \\
\hline REM2 & Remarks \\
\hline REM3 & Remarks \\
\hline FLAG & Flag field-undetermined \\
\hline NEASWAS & Net estimated area weighted average of soil sample average \\
\hline SHIP & A shipment number for reference \\
\hline TLOT & Lot number of track-etch brand devices \\
\hline LLOT & Lot number of Landauer brand devices \\
\hline LCUP4 $4^{e}$ & ID number of 4 th Landauer brand device \\
\hline
\end{tabular}


Table 5. (continued)

\begin{tabular}{ll}
\hline Field Name & \multicolumn{1}{c}{ Explanation } \\
\hline LRN4 & Radon (pCi/L) value of Landauer cup 4 \\
LWL4 & Working level value from Landauer cup 4 \\
AAL4 & Average when 4 Landauer cups were used \\
\hline${ }^{a}$ Three "Landauer" brand alpha-track cups and three "Track-etch" brand cups were placed in the origi- \\
nal properties measured for RDC. This was a comparative study of the two brands to determine the best \\
device to use. Therefore. "L" and "T" preceding the cup ID number, radon value, and working level denotes \\
either a Landauer or a Track-etch device, respectively. \\
bThe three track-etch brand devices (termed "cups") were numbered 4, 5, and 6 to represent the six \\
measurement devices used in the average calculations. \\
'This average working level value was used in the inclusion survey report and recommendation. \\
'This signifies the total counts measured by the GR-410 Portable Gamma Spectrometer (GS). GS \\
measurements were taken on the first several properties that were measured for radon. \\
'Later in the UMTRA Project, four Landauer meters were used and averaged, and therefore a fourth \\
average was calculated for certain properties.
\end{tabular}

Table 6. Descriptive statistics from the radon database

\begin{tabular}{lccrc}
\hline & Minimum & Maximum & Average & Count \\
\hline Records & & & & 325 \\
Placed & $04 / 17 / 86$ & $02 / 14 / 97$ & & 325 \\
Days & 60 & 543 & 323.54 & 311 \\
Average gamma ( $\mu$ R/h) & 1.9 & 63 & 22.91 & 311 \\
Area (m) & 0.9 & 173.4 & 20.55 & 284 \\
Mean Working Level (MWL) & 0.0012 & 0.1437 & 0.0175 & 309 \\
Landauer & & & & \\
MWL Track-etch & 0.0012 & 0.2298 & 0.0193 & 191 \\
MWL Landauer and Track-etch & 0.0006 & 0.1868 & 0.0147 & 311 \\
Gamma spectrometer & & & & \\
$\quad$ Total (counts/min) & 950 & 89,790 & $12,575.36$ & 152 \\
$\quad$ K (counts/min) & 340 & 6,556 & 870.13 & 152 \\
Ra (counts/min) & 121 & 8,729 & 676.03 & 152 \\
Th (counts/min) & 51 & 1,137 & 113.86 & 152 \\
$\quad$ Ra/Th (counts/min) & 1 & 14.18 & 6.05 & 152 \\
Average concrete (pCi/g) & 0.5 & 39.2 & 10.59 & 63 \\
Average soil (pCi/g) & 0.5 & 199.5 & 23.1 & 59 \\
NEAWA concrete (pCi/g) & 0.086 & 13.14 & 1.9889 & 55 \\
NEAWA soil (pCi/g) & 0.007 & 15.7728 & 2.3326 & 48 \\
\hline
\end{tabular}




\section{INDEPENDENT VERIFICATION DATABASE}

The independent verification database holds information regarding ORNL's role as the IVC, a responsibility assigned in 1987 solely for Grand Junction properties with the exception of two properties in Edgemont. A total of 573 properties were surveyed by the IVC in Grand Junction from September 1987 to September 1998. No technical data were recorded in the IVC database; however, data were archived with each respective property at the close of the project, as were all ISC data. When discrepancies or problems arose during an IVC survey, the issues were resolved between ORNL, DOE, and the RAC. By project closeout, all IVC properties were recommended for certification by DOE. 


\section{CONCLUSION}

The UMTRAP ISC databases provide a ready reference to project statistics and may be of value to similar public health programs in the future. Lessons learned during ISC begin with the value of good planning in database construction. It is difficult to maintain consistence over a span of more than a decade; however, ORNL succeeded in doing so with only a few inconsistencies that can be attributed to special studies and projects that are included in the databases. A suggestion in hindsight would have been to include a more technical portion of the database whereby information such as linking gamma exposure rates to soil samples and sizes of mill tailings deposits were documented. This information is available, but only in microfiche reports at this time.

The results of sample analysis for ${ }^{226} \mathrm{Ra}$ contribute valuable information to the field of health physics. In particular, the calculation of background ranges and the presence of naturally occurring radioisotopes in soils and building material are evident from the large amount of data from ISC surveys. These issues will be published in technical journals at a later time. 


\section{REFERENCES}

Espegren, M. L., et al. 1987. Inclusion Survey Contractor Implementation Plan for Fiscal Years 1986-1988. ORNL/TM-10116. Oak Ridge National Laboratory, Grand Junction, Colorado.

Korte, N. E. 1999. A Guide for the Technical Evaluation of Environmental Data. Technomic Publishing Company, Inc., Lancaster, Pennsylvania.

ORNL 1994. Environmental Technology Section (Formerly Pollutant Assessments Group), Procedures Manual, Vols. 1 and 2. ORNL-6645/V2/R2. Oak Ridge National Laboratory, Grand Junction Office, Grand Junction, Colorado.

DOE 1988. Vicinity Properties Management and Implementation Manual. UMTRA

DOE/AL-050601. U.S. Department of Energy, Uranium Mill Tailings Remedial Action Project Office, Albuquerque Operations Office, Albuquerque, New Mexica, March.

EPA 1983. EPA Standards for Remedial Action at Inactive Uranium Mill Processing Sites. U.S. Environmental Protection Agency, Federal Register, Code of Federal Regulations, 40, 192 (January 5, 1983). 
Appendix A

PUBLICATIONS, CONFERENCE PROCEEDINGS, AND TECHNICAL MEMORANDA 


$$
\text { A-2 }
$$




\section{Appendix A}

\section{PUBLICATIONS, CONFERENCE PROCEEDINGS, AND TECHNICAL MEMORANDA}

\section{PUBLICATIONS}

ORNL 1990. Pollutant Assessments Group Procedures Manual. ORNL-6645. Lockheed Martin Energy Systems, Inc., Oak Ridge National Laboratory, Pollutant Assessments Group, Grand Junction, Colorado, October.

ORNL 1992. Pollutant Assessments Group Procedures Manual. ORNL-6645/R1. Lockheed Martin Energy Systems, Inc., Oak Ridge National Laboratory, Pollutant Assessments Group, Grand Junction, Colorado, March.

Ramos, S. J., Berven, B. A., and Little, C. A., 1986. Quality Assurance Program Plan for the Radiological Survey Activities Program-Uranium Mill Tailings Remedial Action Project. ORNL/TM-9684. Lockheed Martin Energy Systems, Inc., Oak Ridge National Laboratory, Oak Ridge, Tennessee.

Espegren, M. L., Carter, T. E., Little, C. A., and Ramos, S. J., 1987. Inclusion Survey Contractor Implementation Plan for Fiscal Years 1986-1988. ORNL/TM-10116. Lockheed Martin Energy Systems, Inc., Oak Ridge National Laboratory, Oak Ridge, Tennessee.

Williams, L. R., Leggett, R. W., Espegren, M. L., and Little, C. A., 1987. Optimization of Sampling for the Determination of the Mean Radium-226 Concentration in Surface Soil. ORNL/TM-10255. Lockheed Martin Energy Systems, Inc., Oak Ridge National Laboratory, Oak Ridge, Tennessee.

Smuin, D. R., Wilson, M. J., and Crutcher, J. W., 1988. Investigation of Background Radiation and Associated Anomalies in Rifle, Colorado. ORNL/TM-10592. Lockheed Martin Energy Systems, Inc., Oak Ridge National Laboratory, Oak Ridge, Tennessee.

Triplett, G. H., Foutz, W. L., and Lesperance, L. R., 1989. Investigation of Background Radiation Levels and Geologic Unit Profiles in Durango, Colorado. ORNL/TM-11067. Lockheed Martin Energy Systems, Inc., Oak Ridge National Laboratory, Oak Ridge, Tennessee.

Wilson, J. E., 1992. A Computer Program Integrating a Multichannel Analyzer with Gamma Analysis for the Estimation of ${ }^{226}$ Ra Concentration in Soil Samples. ORNL/TM-12096. Lockheed Martin Energy Systems, Inc., Oak Ridge National Laboratory, Oak Ridge, Tennessee.

Davidson, J. R., Uranium Series Disequilibrium in the Bargmann Property Area of Karnes County, Texas. ORNL/TM-13539. Lockheed Martin Energy Systems, Inc., Oak Ridge National Laboratory, Oak Ridge, Tennessee.

Ramos, S. J., Carter, T. E., Espegren, M. L., Fenner, D. A., Knott, R. R., Roemer, E. K., and Smuin, D. R., False Exclusion Investigation, Uranium Mill Tailings Remedial Action in Grand Junction, Colorado. Lockheed Martin Energy Research Corp., Oak Ridge National 
Laboratory, Grand Junction Office, Grand Junction, Colorado (unpublished technical memorandum).

Little, C. A., Rice, J. A., Espegren, M. L., Foster, D. S., Jensen, M. K, Jones, A R., Muhr, C. A., Pierce, G., Sauvage, J. R., Smith, S. M., and Zutman, J. L., 1996. Report of Inclusion Survey at Location FC0003I Bargmann Tract, Karnes County, Texas. Lockheed Martin Energy Research Corp., Oak Ridge National Laboratory, Grand Junction Office, Grand Junction, Colorado, September (unpublished technical memorandum).

Rice, J. A., and Halford, D. K., Uranium Mill Tailings Remedial Action Project Inclusion Survey Contractor and Independent Verification Contractor Implementation Plan. Lockheed Martin Energy Research Corp., Oak Ridge National Laboratory, Grand Junction Office, Grand Junction, Colorado (unpublished technical memorandum).

\section{JOURNAL PUBLICATIONS}

Williams, L. R., Leggett, R. W., Espegren, M. L., and Little, C. A., 1989. “Optimization of Sampling for the Determination of Mean ${ }^{226} \mathrm{Ra}$ Concentration in Surface Soil." Environmental Monitoring and Assessment, 12: 83-96.

Berven, B. A., Little, C. A., and Blair, M. S., 1991. "A Method of Automate Radiological Surveys: The Ultrasonic Ranging and Data Systcm." Health Physics, 60(3): 367.

\section{CONFERENCE PROCEEDINGS}

Dickerson, K. S., Espegren, M. L., Lesperance, L. R., and Gardner, F. G., 1987. "Reproducibility of Inclusion Radiological Surveys in DOE's UMTRA Project." In Proceedings of The Oak Ridge Model Conference, Oak Ridge, Tennessee, October.

Little, C. A., Espegren, M. L., and Berven, B. A., 1988. "Progress on the UMTRA Project: The Role of the Inclusion Survey Contractor." In Proceedings of Waste Management '88, Tucson, Arizona, March.

Berven, B. A., Little, C. A., and Blair, M. S., 1989. "A Method to Automate Radiological Surveys: The Ultrasonic Ranging and Data System." In Proceedings of the 28th Hanford Life Sciences Symposium, Battelle Northwest Laboratories, Richland, Washington, October.

Little, C. A., Berven, B. A., Blair, M. A., Dickerson, K. S., and Pickering, D. A., 1989. "The Ultrasonic Ranging and Data System for Radiological Surveys in the UMTRA Project." In Environmental Effects of Decommissioning Nuclear Facilities, Proceedings for the Nuclear Facility Decommissioning Symposium, Nashville, Tennessee, May 9-11, pp. 23-30, American Socicty of Civil Engineers, New York. 
ORNL/TM-1999/175

\section{INTERNAL DISTRIBUTION}

\author{
1-6. M. J. Wilson-Nichols \\ 7. C. A. Little \\ 8. J. E. Wilson \\ 9. M. K. Jensen
}

10. Central Research Library

11-12. Laboratory Records (OSTI)

13. Laboratory Records (RC)

\section{EXTERNAL DISTRIBUTION}

14. M. K. Tucker, U.S. Department of Energy, Grand Junction Office, 2597 B-3/4 Road, Grand Junction, CO 81503

15. F. D. Bosiljevac, U.S. Department of Energy, Pennsylvania \& H Street, Kirtland Air Force Base, Albuquerque, NM 87116

16. J. Elmer, MACTEC ERS, 2597 B-3/4 Road, Grand Junction, CO 81503

17. L. B. Fahy, U.S. Department of Energy, Headquarters, Office of Environmental Restoration \& Waste Management, Room 2130, EM-45 (CLOV), 19901 Germantown Road, Germantown, MD 20874

18. L.Woodworth, U.S. Department of Energy, Albuquerque Operations Office, P.O. Box 5400, Albuquerque, NM 87185-5400

19. Office of Assistant Manager, Energy Research and Development, Oak Ridge Operations Office, P.O. Box 2001, Oak Ridge, TN 37831-8600 
.

$I$

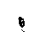

